\title{
ORGANIZATIONAL CHANGE STRATEGIES IN THE ARAB REGION: A REVIEW OF CRITICAL FACTORS
}

\author{
Christopher J. Rees ${ }^{1}$, Rashid Althakhri ${ }^{2}$ \\ Institute for Development Policy and Management, \\ University of Manchester, Manchester, M13, 9GH, United Kingdom \\ E-mail:1'chris.rees@manchester.ac.uk;2r3uae@yahoo.com \\ Received 12 November 2007; accepted 14 March 2008
}

\begin{abstract}
This conceptual paper explores the subject of organizational change in the Arab region with particular reference to cultural influences on organizational change initiatives in this region. The paper offers a review of a set of studies which focus on organizational change in Arab countries and proceeds to discuss change initiatives with reference to factors such as Islam and tribalism. A key issue that emerges from the paper is the paradox between Western approaches to change which emphasize collaborative and participative approaches to change management, and the more directive and hierarchical approaches to management associated with national cultures in the Arab region. Areas for future research are identified in the conclusion section.
\end{abstract}

Keywords: Arab region, organizational change, culture, tribalism, Islam, Islamic values.

\section{Introduction}

The increasing globalisation of markets, competition and organization has led many management scholars to believe that cultures are converging and becoming similar. This belief has raised many questions as to whether management models and practices are capable of being transferred from one country to another. The advocates of the convergence approach argue that management is management, and that it is associated with a set of principles and techniques which can be implemented universally (see Al-Kazemi and Ali 2002; Harris et al. 2003; Schneider and Barsoux 2003; Pugh and Hickson 2004). Nevertheless, it has been observed that management models and practices do vary considerably from country to country (Easterby-Smith et al. 1995; Allinson and Hayes 2000; Aycan et al. 2007). The influential research by Hofstede (1991) demonstrates that management theories often reflect the socio-cultural characteristics of their settings. Implementing these theories in a new context may lead to failure. Similarly, Laurent (1986) stated that managers from different national cultures tend to adhere to their values, norms and beliefs in different contexts.
The opponents of the divergence approach argue that management theory is affected by historical legacy, social values, beliefs and norms, as well as by political and economic systems (Ali 1996; Al-Kazemi and Ali 2002; Jackson 2002). One survey of 11,678 managers in 25 countries found evidence that "the idea of corporate global village where a common culture of management unifies the practices of business around the world is more dream than reality" (Schneider and Barsoux 2003: 7). Notwithstanding this argument, we note that organizations and their employees cannot be separated from the beliefs and social contexts surrounding them. The social context will affect the means by which managers carry out their jobs and seek to implement organizational strategies. Cultural assumptions play a critical role in determining and transferring appropriate management systems and practices (see Furnham 2005; Harris et al. 2003; Jackson 2002; Tayeb 1997; Ginevičienė, Tvaronavičienė 2005). Given the above, the management of organizational change is one significant feature of organizations which is likely to be affected by cultural influences. The main aim of this conceptual paper is to explore key contextual variables 
that impact upon the management of organizational change in the Arab region. For example, the paper provides a critical review of some of the features of Arab culture that may impede the successful implementation of change. Thus, this paper contributes to the generalisability of the existing body of research by exploring the influence of cultural influences on change management in the Arab world.

\section{The context of the Arab region}

The Arab region, which contains countries as far as Iran in the east and countries in North Africa up to Morocco in the West, has generated limited research relating to the impact of culture on change management. This lack of research on change management is somewhat surprising given that the region has witnessed fundamental political, economic, and social changes, as evidenced by urban expansion, population increases and the growth of commercial enterprises. The discovery of oil and the dramatic increase in the oil price after 1973 has had a great impact in changing Arab societies and played a role in creating an unstable environment, especially in the Arabian Gulf societies (Ali 1990; Al-Kazemi and Ali 2002). Before the discovery of oil, Arab societies comprised a generally poor region which relied on seafaring, pearling and limited trade (Abdalla 1997). However, since the Second World War, the oil-rich Muslim countries of Middle East have exerted a great influence over the whole business world (Furnham 2005).

Currently, the economies of the Arab region are dominated by the oil sector. The investment in the oil sector has enabled Arab counties to develop education, health and social protection systems and increase trade (Eken et al. 2003). Abed (2003) indicates that the Arab region accounts for approximately 2.6 per cent of the world Gross Domestic Product (GDP). However, this figure should be treated cautiously as there is a significant gap between the richest and poorest countries in the Arab World. Eken et al. (2003) claim that 30 percent of the Arab World's people are living on less than \$ 2 a day (with people in countries such as Sudan, Yemen and Somalia facing particular economic hardships). These authors indicate some Arab countries are not achieving effective economic reforms because of structural factors including: 1) unstable political systems and security concerns which divert public resources away from development and investment; 2) economic and institutional restrictions such as the dominant role of governments, rigid regulations that impede private sector development and rigid labour markets; and
3) population growth which puts pressure on the government to provide social services. This view has been supported by Abed and Davoodi (2003) who claim that there are some key elements which restrict some Arab countries from benefiting fully from globalisation. The first is the relatively high levels of population growth in Arab countries. Arab countries have had one of the highest rates of population growth in the world with a 2.5 percent annual increase over the past 20 years. The second element is lagging political reforms. Authoritarian regimes in some Arab countries remain an obstacle to economic development. The Arab Human Development Report (United Nations 2002) found that the Arab region performs poorly in terms of political freedom and in the development of human skills and knowledge. However, some Arab countries (for example, Kuwait and United Arab Emirates) have started to reform their political systems and introduce more democratic regimes in order to enhance their economies (see Patrick et al. 2006). The third element is the dominance of the public sector. The huge public sector in the Arab world adversely affects economic systems in a number of ways. This general inefficiency of the public sector is manifest in, for example, the high cost of revenue collection, delays in obtaining licenses or permits to start businesses, complex court systems and the generally poor quality of public services. Thus, the costs of establishing new businesses in the Arab region are reported as being five times as high as in East Asia and 2.5 times as high as in Eastern Europe and Central Asia (Abed and Davoodi 2003: 15). Al-Yousif (2004) reports that the public sector in the Arab region accounts for 60 percent of GDP which in turn places major constraints on attempts to develop the private sector.

Mellahi (2003) and Rees et al. (2007) have suggested that since the $1970 \mathrm{~s}$, oil revenue has been employed to develop and enhance the public sector in the Arab region which in turn has enabled governments to provide relatively well-paid employment to indigenous workforce. As a consequence of relatively favourable terms of employment, locals actually prefer to work in the public sector rather than to work in private sectors. This situation has led some countries such as Saudi Arabia, Oman and Untied Arab Emirates to adopt nationalization strategies in order to encourage the private sector to employ locals (see, Rees et al. 2007). However, the private sector has tended to resist nationalization programmes for various reasons. These reasons include the following: 1) Private sector companies prefer foreign (or expatriate labour) as it is cheaper. Thus, even though governments have pressurised the private sector to reduce its hiring of foreign labour by means of 
strategies such as legal quotas and the introduction of high charges for issuing and renewing work permits, locals are still relatively expensive to employ. 2) Social and cultural features are important to locals as they prefer to avoid the manual and technical jobs which are more numerous in the private sectors. 3) Managing expatriates is generally easier because expatriates fear the termination or non-renewal of employment contracts and deportation from the country. 4) The final reason is that the locals often avoid social integration in the multinational work environment in order to maintain a high social status (Rees et al. 2007).

\section{Organizational change in the Arab region}

As noted above, there are a limited number of studies available on organizational change in the Arab region (Al Blori 2005) though, as a whole, the body of literature that has emerged does highlight the importance of this subject for the future economic development of the region. Thus, Alqahtani (2006) argues that the absence of a strategic organizational change and development agenda has led to some of the specific problems in the Arab region which are discussed above including the region's reliance on foreign workers, high unemployment rates among indigenous populations, a general lack of loyalty to organizations, the undue influence of the tribal system and family relationships within companies, the spread of administrative corruption, conflict between ministries in terms of their responsibilities and a lack of interaction with international players. Against this background, Alqahtani (2006) emphasises the importance of change management as a powerful strategy to reform public sector organizations and deal with these issues. Similarly, Alfawari and Alamari (2000) surveyed a group of 200 managers to examine their attitudes towards organizational development and change in the service sector in Qatar. They point out that one of the most important problems facing the process of management development in Qatar is the absence of clear strategies for organizational change and development.

As part of this review paper, we have sought to summarise a group of studies that focus on organizational change in the Arab region (see Table 1). We focus on these studies as they were available from a search on organizational change conducted in a University library in Abu Dhabi. Interestingly, most of these studies were published in media found in the Arab region as opposed to Western literature. This review offers a summary of these studies, including their objectives, methods and main findings.

Table 1. Review of organizational change management literature in the Arab region

\begin{tabular}{llll}
\hline \multicolumn{1}{c}{ Author(s) } & \multicolumn{1}{c}{ Objective(s) } & Research method & \multicolumn{1}{c}{ Conclusion } \\
\hline $\begin{array}{lll}\text { Alhalawani } \\
(1990)\end{array}$ & $\begin{array}{l}\text { To investigate the role of } \\
\text { change in management } \\
\text { development }\end{array}$ & $\begin{array}{l}\text { Questionnaire } \\
\text { survey }\end{array}$ & $\begin{array}{l}\text { The study found that: 1) change must be planned } \\
\text { and implemented carefully in order to be successful; }\end{array}$ \\
& & $\begin{array}{l}\text { 2) change should not be based on personal objec- } \\
\text { tives, 3) attention should be paid to motivation sys- } \\
\text { tems and negotiation with employees by informal } \\
\text { channels in order to persuade employees to accept } \\
\text { change and 4) successful change should not be con- } \\
\text { tinuous, because permanent change might lead to } \\
\text { the creation of a state of fear and suspicion among } \\
\text { employees. }\end{array}$ \\
\hline
\end{tabular}

Abu-Hamdieh's To examine the impact study (1994) of the participation of employees, the relationships between them and the availability of information on change processes

\section{Alzni (1994)}

To examine the role
Questionnaire was used with 1,917 employees in 40 industrial companies in Jordan of communications in organizational change
Questionnaire was used with 154 employees from the Cairo Saudi Bank
The author reports that participation, good relations between employees at work and availability of information have a positive correlation with effective change processes, while age and the nature of work have significant correlations with resistance to change. By contrast, sex, education and work experience were found to have no association with resistance to change.

The findings highlight the need for effective communication between employees by providing them with adequate information about change in order to implement change successfully. Managers should increase confidence in their employees and encourage them to participate in change processes. 
Continue of Table 1

\begin{tabular}{lll}
\hline \multicolumn{1}{c}{ Author(s) } & \multicolumn{1}{c}{ Objective(s) } & Research method \\
\hline Alkadera & To investigate & Questionnaire was \\
and Alfawori & managerial attitudes & used with a sample \\
$(1994)$ & towards organizational & of 300 managers \\
& development in Jordan & from all ministries \\
& & and governmental \\
& & institutions
\end{tabular}

\begin{tabular}{ll}
\hline Allozi (1999) & $\begin{array}{l}\text { To examine employees' } \\
\text { attitudes towards } \\
\text { organizational change }\end{array}$
\end{tabular}

Questionnaire was used with a sample of 603 employees from 23 public sector institutions in Jordan

\section{Conclusion}

The findings show that a majority of the managers agreed that organizational development was a part of their task. Results also indicate that organizational development in Jordan was facing many challenges: recruitment was not based on employees' capabilities, the monitoring of the process of organizational development was poor, there was a lack of sufficient power for those in charge of organizational development and of qualified specialists in aspects of management development.

The findings indicate that employees' participation in the change process is one of the most important factors in helping to implement change. The study found that change from an employee perspective is considered as a threat. On the other hand, managers tend to have more positive views of organizational change.

\begin{tabular}{lll}
\hline Alamri and & To examine the causes of & Questionnaire was \\
Alfawsan & resistance to change in & used with sample \\
(1997) & the public sector in Saudi & of 450 employees \\
& Arabia &
\end{tabular}

The results indicate that employees resist change for several reasons. First, managers are concerned about losing their power while members of staff fear the loss of their jobs. Secondly, objectives and action plans for change processes are often unclear to employees. The authors consider that the most important factor leading employees to resist change is unclear channels of communication between employees and change agents.

\begin{tabular}{lll}
\hline Almuslimani & $\begin{array}{l}\text { To examine the obstacles } \\
\text { to organizational } \\
\text { development in Jordan }\end{array}$ & $\begin{array}{l}\text { Questionnaire } \\
\text { survey }\end{array}$ \\
&
\end{tabular}
The study identifies specific obstacles to organizational development. They are: lack of financial support, centralization of authority, rigid procedures and regulations, and certain social values, including tribalism, family relationships and favouritism.

\begin{tabular}{ll}
\hline Alzuadat & To explore the role of \\
training in situations \\
where organizational \\
change results in the \\
creation of new jobs
\end{tabular}

Questionnaire
survey was used
with a sample of
370 employees
from a commercial
bank in Jordan

The study finds that training programmes should be given more attention, especially when a change requires new jobs in order to help employees to gain new capabilities and skills that are necessary for their new status. The study also reports that, in order to implement change successfully, employees should participate in decision-making.

\begin{tabular}{ll}
\hline Alomari (2000) & To identify a number \\
& of factors that impede \\
& change management in \\
& a telecommunication \\
& company in Saudi Arabia
\end{tabular}

Questionnaire was used on a sample of 350 employees

The study found that factors which impede change include: 1) poor planning and implementation of change, 2) a lack of human and material resources allocated to the change programme, 3) change objectives which are not clear to employees, 4) a lack of participation by employees in the change process and 5) managers are anxious about losing their power and influence.

\begin{tabular}{|c|c|c|c|}
\hline Alharbi (2002) & $\begin{array}{l}\text { To examine resistance } \\
\text { to change in public } \\
\text { institutions in Saudi } \\
\text { Arabia. Also to identify } \\
\text { the relationships between } \\
\text { resistance to change and } \\
\text { demographic variables }\end{array}$ & $\begin{array}{l}\text { Questionnaire was } \\
\text { used on a sample } \\
\text { of } 348 \text { employees }\end{array}$ & $\begin{array}{l}\text { The study concludes that there are two main factors } \\
\text { creating resistance to change: poor planning and } \\
\text { management of change and the fact that managers } \\
\text { have no confidence in their employees. The study } \\
\text { shows that the demographic variables examined do } \\
\text { indeed have a significant correlation with resistance } \\
\text { to change. }\end{array}$ \\
\hline
\end{tabular}


End of Table 1

\begin{tabular}{|c|c|c|c|}
\hline Author(s) & Objective(s) & Research method & Conclusion \\
\hline $\begin{array}{l}\text { Aldkasma } \\
((2002\end{array}$ & $\begin{array}{l}\text { Investigates the factors } \\
\text { influencing change in a } \\
\text { government department } \\
\text { in Jordan. Also examines } \\
\text { the obstacles to such } \\
\text { change }\end{array}$ & Questionnaire & $\begin{array}{l}\text { The study found that improvement of organizational } \\
\text { performance is the most important driver of organi- } \\
\text { zational change and that among the various chal- } \\
\text { lenges faced by this change are: 1) poor participa- } \\
\text { tion by employees in the change process, } 2 \text { ) neglect } \\
\text { of the monitoring of the process, } 3 \text { ) a failure to re- } \\
\text { inforce the new status quo and } 4 \text { ) a lack of financial } \\
\text { and moral support. }\end{array}$ \\
\hline Alazam (2002) & $\begin{array}{l}\text { To investigate attitudes } \\
\text { towards organizational } \\
\text { development and } \\
\text { change in a Jordanian } \\
\text { communications } \\
\text { company }\end{array}$ & $\begin{array}{l}\text { Questionnaire was } \\
\text { used on a sample } \\
\text { of } 160 \text { managers }\end{array}$ & $\begin{array}{l}\text { The result shows that external and internal environ- } \\
\text { ments must be analyzed carefully before any deci- } \\
\text { sion is taken to initiate change. The author states } \\
\text { that the organization needs to adopt a flexible or- } \\
\text { ganizational structure and improve communication } \\
\text { systems in order to implement change effectively. }\end{array}$ \\
\hline Abdah (2006) & $\begin{array}{l}\text { To investigate the } \\
\text { relationship between } \\
\text { leadership styles } \\
\text { and organizational } \\
\text { development in different } \\
\text { government ministries in } \\
\text { Jordan }\end{array}$ & $\begin{array}{l}\text { Questionnaire was } \\
\text { used on a sample } \\
\text { of } 397 \text { managers }\end{array}$ & $\begin{array}{l}\text { The findings show that in order to improve organiza- } \\
\text { tional development in the Central Ministries, atten- } \\
\text { tion should be paid to delegating authority to staff, } \\
\text { simplifying work procedures, reviewing legislation } \\
\text { and regulations, and improving communication } \\
\text { channels between managers and staff. }\end{array}$ \\
\hline
\end{tabular}

As can be seen from Table 1, research in the area of change management has provided information about why employees resist organizational change in both private and public sectors in some Arab countries. One of the most important factors leading subordinates to resist change appears to be poor planning and implementation of change. The studies have tended to show that there are other reasons and symptoms associated with resistance to organizational change in this region. These include the following: 1) Managers being concerned about losing their position and power. 2) Staff members fearing the loss of their jobs. 3) Unclear change management objectives. 4) A lack of trust in employees. 5) Ineffective communication between employees and change. 6) A lack of recognition of the need to change. It is clear that in many cases these factors can be described as both a cause of resistance to organizational change but also as a symptom of resistance to organizational change. This has led some researchers to explore specific cultural variables in the Arab region which may impact heavily upon both the design and acceptance of organizational change initiatives. These cultural variables are seen by some to shape management practice in this region (see Ali 1990; Bakhtari 1995; Tayeb 1997; Mellahi 2003). In this paper, we highlight the impact of certain cultural influences on the theory and practice of organizational change in the Arab region.

\section{Arab culture and the workplace}

In this section, we seek to explore various cultural influences which are likely to impact upon organizational change initiatives in the Arab region. The first of these influences is Islam and Islamic values (Darwish 2000, 2001). Islam is regarded as one of the most important factors which shapes current Arab values, norms and beliefs (Bakhtari 1995; Darwish 2001). At a general level, Tayeb (1997) indicates that religions in many countries, with either secular or religious constitutions, play a critical role in shaping the cultural characteristics of their people and their organizations. More specifically, Al-Shaikh (2003) argues that Islam is not only a religion that provides the relationship between people and Allah (God), but to believers it organizes all features of life including business, economics, political and social issues. The Islamic work ethic is based on the 'Holy Quran' and the sayings of 'Prophet Mohammed' (Ali 1996). According to Furnham (2005), business in Islamic societies cannot be separated from Islamic regulations and rules. According to Darwish (2001), Islam encourages people to be honest and just in business and trade. Cooperation and consultation in work are encouraged in order to overcome obstacles and avoid mistakes. The Islamic work ethic emphasizes that social relations at work meet an individual's needs and create balance between the individual's work and social life. In one overview, Mellahi (2003) 
has sought to identify the values of Islam that impact directly on working life. For example, he highlights that in Islamic tradition, laziness is a vice and dedication to work is a virtue. Further, justice and generosity in the workplace are necessary conditions for society's welfare and the value of work is derived from the accompanying intention rather than its result.

Despite the fact that the Islamic work ethic is a common concern to Muslims across the world, the Arab region should not be considered as a typical example of the implementation of Islamic rules and regulations. This is because many Muslims in this region have been influenced by capitalism, socialism, and secularism (see Al-Shaikh 2003). Therefore, differences between Islamic countries can be observed in economic and business systems as well as social contexts. For instance, Saudi Arabians are committed to implement the Islamic law (Sharia) in many aspects of life, while Turkey has introduced secular law in order to organise its economic, business and social affairs (see Tayeb 1997). Given these differences, it is notable that various researchers have sought to explore the extent to which Islamic values are actually evident in the workplace. For example, Ali and Al-Kazemi (2007) studied the influence of Islamic work ethics on the lives of managers in Kuwait; their results from a sample of 762 managers and an Islamic work ethic scale show that managers have a high commitment to Islamic work ethics. Related information has been provided by Hunt and Al-Twaijri (1996). They argue that Saudi managers are committed to the Islamic work ethic and a moderate tendency toward individualism. They indicate that Saudi Arabian culture is strongly affected by Islamic values and tribalism systems. Darwish (2001) investigated the moderating impact of the Islamic work ethic on the relationships between organizational commitment and job satisfaction, using a sample of 425 Muslim employees in 30 organizations in the United Arab Emirates. The result indicates that employees are highly committed to the Islamic work ethic. The relationships between the Islamic work ethic and both factors - job satisfaction and organizational commitment are positive. The results show that those who strongly adhere to the Islamic work ethic are more committed to their organizations and more satisfied with their jobs.

In addition to Islamic values, tribal systems are another influential factor on Arab management and practices. Tribalism is often sanctioned into present political, economic and management systems in the Arab region (see Ali 1990, 1995; Mellahi 2003; Lewis 2006). The Arab culture is traditional, family oriented, male dominated and conservative in risk taking (Bakhtari 1995).
The tribal approach helps to establish the authoritarian structure within public and private sectors in the Arab region. Ali (1995) indicates that the characteristics of authoritarian tribalism embrace an open door policy, hierarchical structures and centralization of decisionmaking. Regulations and rules are dependent on the person who holds a power position within the hierarchical structure. In Arab societies, tribalism can be described as "rigid, uncreative, believers in myths, risk avoiders, imposers of their values and rules on others, dichotomous in their view of right and wrong, and strictly adhere to the established norms of society" (Ali 1998, P5).

It has been argued that Arab tribal values reinforce the concept of consultative and participative decision style. For example, Ali et al. (1997) surveyed a group of 307 managers in Kuwait to examine individualismcollectivism concepts along with decision style. The result showed that managers tend to prefer consultative and participative decision styles. Similarly, Darwish (2000) examined the role of organizational culture and the level of technology used in organizations as predictors of decision-making style in the United Arab Emirates. The result indicated that there is tendency toward participative and consultative styles in decision making. However, although consultative and participative styles are the most common decision-making styles in Arab culture, decisions are taken without subordinates and are not delegated down the hierarchy (see Dedoussis 2004). It has been argued (Tayeb 1997) that participation in decision making might be considered by subordinates as a management weakness in Arab culture and further, managers and subordinates in Arab societies tend to dislike teamwork. Arab tribal values also place a strong emphasis on commitment and obedience as both represent essential elements of tribal systems (see Abdalla et al. 1998). Thus, nepotism may be openly allowed in the Arab world in order to fulfill the individual's responsibilities toward their relatives and extended family. Moreover, nepotism is often apparent in the recruitment of upper level managers, though qualifications are stressed in the selection of middle managers and lower-level employees (see Ali 1995; Hutchings and Weir 2006). Further, managerial issues associated with tribalism have been identified in Arab societies especially in Arabian Gulf. For example, a survey of 210 employees in private and public sectors in the United Arab Emirates found that there have been serious managerial problems such as centralization of authority, inadequate information system and planning, taking comments at work as personal criticism, and evidence of a weak inclination toward research and theories (Ali and Azim 1996). Similarly, Al-Kazemi 
and Ali (2002) investigated managerial problems in Kuwait using a sample of 762 mangers. They found that the most important managerial problems are favouritism and personal loyalty at work, unwillingness to take responsibility, rigid administrative systems and policies, primacy of personal relationships over work relationships, subjectivity in appraisal and promotion, reliance on hereditary relations and a variety of rules which conflict with each other. They find that these problems are ascribed to tribal thought which is prevalent in Kuwait society.

When one combines the influences of tribalism with the values associated with Islam, some of the features of the Arab region which have, in the past, been explored and identified using Hofstede's typology become more understandable. Using the cultural dimensions of Hofstede it is worth noting that Arab world are typically represented as countries dominated by strong uncertainty avoidance, large power distance, high collectivism and masculinity orientation (see Hofstede 1991; Kalliny et al. 2006). Many of the empirical researches that have been conducted in the Arab region confirm Hofstede's findings. For instance, Kabasakal and Bodur (2002) argue that Arab countries are similar in social culture. They tend to be strongly group oriented, hierarchical, masculine and low on future orientation. Budhwar and Mellahi (2007) point out that the Arabian Peninsula is dominated by traditional sheikhdoms and autocratic systems. They indicate that human resource management in, for example, Oman has been affected by Islamic values, tribes and families. In the way of an explanation, Mellahi (2003) suggests that large power distance in the Arab world might be ascribed to Muslims' values which relate to respect for authority as well as tribalism or Bedouin systems. He argues that Arab world is dominated by strong uncertainty avoidance. This is because people in Arab societies have "lower tolerance for new ideas, lower degree of initiative for bringing about change, fatalism, unquestioning acceptance of conventional wisdom and obedience of justified authority" (Mellahi 2003: 98). Moreover, the Arab world is highly collectivist within their tribe and highly individualist with out-groups (see Bakhtari 1995; Mellahi 2003).

We recognize, of course, that the Arab region is vast and contains many diverse cultures that are constantly in a state of flux. For example, although the Arab world is dominated by Islamic values and tribalism, there is emerging evidence of a tendency in certain quarters toward contemporary Western management theory and practice. Aycan et al. (2007) surveyed a group of 712 employees working in six large organizations in Oman in order to examine the impact of cultural orientations on employee preferences of human resource policies and practices. The findings show a high orientation towards mastery, harmony, thinking and doing and low orientation towards hierarchy and collectivism. These findings contrast with the historical background of Oman - a context that is based around a tribal system. Related information has been provided by the GLOBE project. This project examined cultural values and work behaviours in 62 countries including the Arab countries of Kuwait, Egypt, Morocco and Qatar. The project found that Arab countries have high tendency towards future and performance orientations and are low on power distance (quoted form Aycan et al. 2007). However, at a more general level, it is argued that organizations in the Arab region have not adopted Western attitudes, values and norms; Budhwar and Mellahi (2007) indicate that Arab countries still have management systems similar to most other developing countries that concentrate on local cultural values, beliefs and norms.

\section{The implications of Arab culture on organizational change initiatives}

It has been argued (see Harris et al. 2003; Schneider and Barsoux 2003; Aycan 2005) that national cultures differ in terms of planning for change and strategy. For example, in societies whose culture is dominated by strong uncertainty avoidance and long term orientation, change is likely to be regarded as a threat; therefore, more detailed plans are required in order to resolve ambiguous situations. On the other hand, in societies with a low degree of uncertainty avoidance and short term orientation, people tend to be more tolerant of change, thus, they may be less resistant to change.

In relation to organizational change in the Arab region, it is reasonable to assert that planning for change will be affected by cultural variables such as religion and tribalism (see Furnham 2005; Schneider and Barsoux 2003; Mead 2005). For example, in many Muslim societies, long-term planning might be inappropriate. This is because many Muslims believe that only God (Allah) can foresee future. Planning for the future is based on Insh Allah, that is, 'as God wills'. Furnham (2005) argues that change in Muslim societies, may be viewed as unnecessary or in the hands of God ( $A l$ $l a h$ ) and people tend to prefer the status quo. (It is not within the scope of this paper to discuss the theological accuracy of this view of change in relation to the tenets of the Muslim faith. However, we do recognize that the view that sees the future as in God's hands does not 
necessarily conflict with planning for the future. In fact some Islamic teachers urge Muslims to be productive in their life and Muslim scholars highlight the rewards afforded to those who work both conscientiously and systematically.)

In addition, managerial approaches to change management are also influenced by tribalism. Consequently, managers, in Arab societies tend to prefer a stable environment and avoid change within organizations. Strong leadership is required in order to direct employees to organizational goals (see Ali 1998). Thus, organizational change must be determined by the manager who holds a position of power within the hierarchical structure of the organization. This is because the manager is seen to hold legitimate authority to initiate change in the organization. Support for this perspective was found by Mead (2005) who showed that, in countries dominated by large power distance, such as in the Arab World, managers are seen to have the right to plan for change and subordinates have no authority to make plans. Thus, subordinates expect to receive detailed plans for change from managers without necessarily participating in the decision-making process. Moreover, he argues that monitoring the process of implementation of organizational change is not taken seriously in these societies. Therefore, change management in the Arab world is "slow placed, centrally controlled, and aimed at achieving technical rationality and efficiency" (Cummings and Worley 2001: 560).

As can be seen, successful implementation of change in Arab World requires strong direction from managers who hold positions of power within organizational structures. However, Ford (2006) indicates that planned change has a high rate of failure, estimated at 70 per cent, with less than 10 per cent of failures ascribed to technical issues. This high failure rate of change initiatives is explained by its dependence on positional power in order to initiate and manage change. This dependence runs contrary to traditional change management theory which posits that power should be transferred to employees in order to implement organizational change successfully. Moreover, Bamford and Forrester (2003) indicate that successful change should not be dependent on top-down command and control of management. This is because the environment is complex and dynamic making it difficult for senior managers to be able to identify appropriate plans and implementation strategies.

In addition, Arab societies are dominated by strong uncertainty avoidance which requires more detailed plans for change. However, the complex and dynamic nature of external environment make planning very difficult and Dawson (1994: 181) argues that "it is impossible to predict all future scenarios or adapt to unexpected consequences of political decision-making and power plays during the process of change". Consequently, organizational change should be regarded as a continuous open-ended process rather than sequences of pre-planned steps (see Burnes 2004; Todnem 2005). This difficulty in planning change in the Arab region is exacerbated by the common perception of time as unlimited and flexible (see Schneider and Barsoux 2003). Therefore, plans for change are changed according to circumstances (Mead 2005).

\section{Conclusions}

This paper has reviewed the implications of aspects of Arabic culture on management systems in general and specifically in relation to the successful implementation of organizational change. It has focused on the some of the influential factors that shape Arabic culture and their effect on the management of change. In spite of some research that supports the notion that management practices can be implemented universally, management systems vary significantly from country to country. Such disparities in practices are attributed to cultural assumptions held by people in their localities. Thus, cultural assumptions play a critical role in determining and transferring appropriate management systems and practices.

Generally, the Arab world tends to be strongly group oriented, male-oriented and dominated by large power distance, strong uncertainty avoidance, and long term orientation. This is reflected in the tribal systems adopted by the majority of Arab societies. These cultural characteristics exert a great influence on management systems in general and organizational change in particular. In Arab societies, change is often considered as a threat and people prefer the status quo. Therefore, the successful implementation of change in Arab contexts requires strong support from senior management, especially those who have power position within the organizational structure.

It can be argued that the cultural values of the Arab world differ from country to country and might be changed over time in order to meet the standards required by international businesses. However, this review concludes with the suggestion that further studies are needed to explore three specific issues. First, there is a clear need to explore further the impact of Arab culture on the successful implementation of change in different areas of the Arab region. Second, we highlight the need for research that investigates the readiness of people and organizations operating within the Arab re- 
gion to accept Western models of change. Third, there is a scarcity of research that has examined change management approaches that are compatible with Arabic culture; for example, there is a specific need for this research to focus upon the efficacy of directive change management leadership in Arab contexts.

\section{References}

Abdalla, I. 1997. Construct and concurrent validity of three protestant work ethic measures in an Arabian Gulf society, Journal of Managerial Psychology 12(4): 251-260.

Abdalla, H.; Maghrabi, A.; Raggand, B. 1998. Assessing the perceptions of human resource managers toward nepotism, International Journal of Manpower 19(8): 554-570.

Abdeh, D. 2006. Leadership styles and organisational development in the Central Ministries of Jordan. Jordan: Government of Jordon.

Abed, G. 2003. Unfulfilled promise, Finance and Development, 40(1): unpaged [accessed 7 December 2007]. Available from Internet: <www:imf.org/external/pubs/ft/ fandd/2003/03/abed.htm $>$.

Abed, G.; Davoodi, H. 2003. Challenges and growth in globalizations in the middle east and North Africa [accessed 2 December 2007]. Available from Internet: <http://www. imf.org/external/pubs/ft/med/ara/abed>.

Abu-Hamdieh, A. 1994. Employees 'perspectives on organizational change and the contribution of industrial companies in Jordan. Unpublished Master's dissertation. University of Jordan, Faculty of Economics and Administrative Sciences.

Alamri, A.; Alfawsan, N. 1997. Staff resistance to change in the public sector in Saudi Arabia: causes and remedy, Public Administration Journal 37(3).

Alazam, Z. 2002. Managers' perspectives towards Organizational Development in the Jordanian communications company. Unpublished Master's dissertation: University of Yarmouk.

Al Blori, S. 2005. Staff attitudes towards the organizational change: a survey study in civil aviation in Jeddah. Naif Arab University for Security Sciences, KSA.

Aldkasma, M. 2002. Attitudes of managers toward organizational change in governmental departments in Irbid / Jordan: An Empirical Study. Administration No 88.

Alhalawni, A. 1990. Change and its role in management development, Public Administration 67: 45.

Alharbi, A. 2002. Resistance to change: an empirical study in public institutions in Jeddah / Saudi Arabia. Unpublished Master's dissertation: University of King Abd-Alaziz.

Ali, A. 1990. Management theory in a transitional society: the Arab's experience, International Studies of Management and Organization 20(3): 7-35.

Ali, A. 1995. Cultural discontinuity and Arab management thought, International Studies of Management and Organization 25(3): 7-30.
Ali, A. 1996. Organizational development in the Arab World, Journal of Management Development 15(5): 4--21.

Ali, A. 1998. The typology of the Arab individual: implications for management and business organizations, International Journal of Sociology and Social Policy 18(11): $1-19$.

Ali, A.; Al-Kazemi, A. 2007. Islamic work ethic in Kuwait, Cross Cultural Management: An International Journal 14(5): 93-104.

Ali, A.; Azim, A. 1996. A cross-national perspective on managerial problems in a non-western country, The Journal of Social Psychology 146(2): 165-172.

Ali, A.; Taqi, A.; Krishnan, K. 1997. Individualism, collectivism, and decision styles of managers in Kuwait, Journal of Social Psychology 137(5): 629-637.

Alkadera, B.; Alfawori, R. 1994. Attitudes of middle managers towards organisational development in Jordan. Yarmouk University, Research Centre of Jordan, Irbid.

Al-Kazemi, A.; Ali, A. 2002. Managerial problems in Kuwait, Journal of Management Development 21(5): 366-375.

Allinson, C.; Hayes, J. 2000. Cross-national difference in cognitive style: implications for management, International Journal of Human Resource Management 11(1): 161-170.

Allozi, M. 1999. Employees' attitudes to organisational changes in governmental institutions in Jordan, The Magazine Studies 2: 338.

Almuslimani, H. 1999. Evaluating the effectiveness of organisational development in Jordan and its obstacles from an employee perspective. Jordan: Government of Jordan.

Alomari, Z. 2000. Challenges to change strategy for managing change: an empirical study in a Saudi Arabian telecommunication company. Unpublished Master's dissertation: King Saweed University.

Alqahtani, F. 2006. Organisational development, reform strategies and their role in reinforcing national security. Unpublished PhD thesis: University of Naife, Saudi Arabia.

Al-Shaikh, F. 2003. The practical reality theory and business ethics in non-western contexts, Human Management Development 22(8): 679-693.

Al-Yousif, K. 2004. Globalization and economic development in GCC. Paper presented at American Economic Association Conference in Santiago, USA.

Alzni, A. 1994. Communication from a behavioural perspective and its role in organisational change: an empirical study in the Cairo Saudi Bank. Unpublished Master's dissertation: University of King Abd-Alaziz.

Alzuadat, K. 1999. Factors affecting employees' attitudes toward organizational change in Jordanian commercial banks. Unpublished Master of BusinessAdministration dissertation: University of Al Albate.

Anwar, S; Chaker, M. 2003. Globalisation of corporate America and its implications for management styles in an Arabian cultural context, International Journal of Management 20(1): 43-56. 
Aycan, Z. 2005. The interplay between cultural and institutional/structural contingencies in Human Resource Management practices, International Journal of Human Resource Management 16(7): 1083-1119.

Aycan, Z.; Al-Hamadi, A.; Davis, A.; Budhwar, P. 2007. Cultural orientations and preferences for HRM policies and practices: the case of Oman, International Journal of Human Resource Management 18 (1): 11-32.

Bakhtari, H. 1995. Cultural effects on management style: a comparative study of American and Middle Eastern management styles, International Studies of Management and Organization 25(3): 97-118.

Bamford, D. 2006. A case-study into change influences within a large British multinational, Journal of Change Management 6(2): 181-191.

Bamford, D.; Forrester, P. 2003. Managing planned and emergent change within an operations management environment, International Journal of Operations and Production Management 23(5): 546-564.

Burnes, B. 1996. No such thing as... a "one best way" to manage organizational change, Management Decision 34(10): 11-18.

Burnes, B. 2004. Managing change, $4^{\text {th }}$ edition. Pearson Education Limited, England.

Budhwar, P.; Mellahi, K. 2007. Introduction: human resource management in the Middle East, International Journal of Human Resource Management 18(1): 2--10.

Cummings, T.; Worley, C. 2001. Organization development and change, 7th edition, USA: Thomson South Western.

Darwish, Y. 2000. Organizational commitment as a mediator of the relationship between Islamic work ethic and attitudes toward organizational change, Human Relations 35(4): 513-537.

Darwish, Y. 2001. Islamic work ethic: a moderator between organizational commitment and job satisfaction in a crosscultural context, Personnel Review 30(2): 152-169.

Dawson, P. 1994. Organizational change: a processual approach. London: Paul Chapman.

Dedoussis, E. 2004. A cross-cultural comparison of organizational culture: evidence from Universities in Arab World and Japan, Cross Culture Management 11(1): 15-34.

Easterby-Smith, M.; Malina, D.; Yuan, L. 1995. How culture-sensitive is HRM? A comparative analysis of practice in Chinese and UK companies, The International Journal of Human Resource Management 6(1): 31-59.

Eken, S.; Robalino, D.; Schieber, G. 2003. Living better, Finance and Development 40(1): unpaged [accessed 7 December 2007]. Available from Internet: <www: imf.org >.

Ford, F. 2006. Organizational learning, change and power: toward a practice-theory framework, The Learning Organization 13(5): 495-524.

Furnham, A. 2005. The psychology of behaviour at work, $2^{\text {nd }}$ edition. England: Psychology Press.
Ginevičienė, V.; Tvaronavičienè, M. 2005. Trends and level of development: view to new EU members, Journal of Business Economics and Management 6(2): 20-28.

Harris, H.; Brewster, C.; Sparrow, P. 2003. International human resource management. London: CIPD.

Hofstede, G. H. 1991. Cultures and organizations: software of the mind. London: McGraw-Hill.

Hunt, D.; Al-Twaijri, M. 1996. Values and the Saudi manager: an empirical investigation, Journal of Management Development 15(50: 48-55.

Hutchings, K.; Weir, D. 2006. Understanding networking in China and the Arab world, Journal of European Industrial Training 30(4): 272-290.

Jackson, T. 2002. The Management of people across cultures: valuing people differently, Human Resource Management 41(4): 455-475.

Kabasakal, H.; Bodur, M. 2002. Arab cluster: a bridge between East and West, Journal of World Business 37 : 40-54.

Kalliny, M.; Cruthirds, K.; Minor, M. 2006. Differences between American, Egyptian and Lebanese humour styles, International Journal of Cross Cultural Management 6(1): 121-134.

Laurent, A. 1986. The cross cultural puzzle of international human resource management, Human Resource Management 25(1): 91-102.

Lewis, R. 2006. When cultures collide: leading across cultures, 3rd edition. London: Nicholas Brealey International.

Mellahi, K. 2003. National culture and management practices: the case of Gulf Cooperation Council Counties, in M. Tayeb (ed.). International Management: Theories and Practices. UK: Prentice Hall, 88-105.

Patrick, N.; Murphy, E.; Nonneman, G. 2006. Political reform in GCC. UK: The Foreign Policy Center [accessed 5 December 2007]. Available from Internet: <www. Fpc. org.uk/topics/civility/>.

Pugh, D.; Hickson, D. 2004. On organizational convergence, in M. Warnar and P. Joynt (eds.). Managing across cultures: issues and perspectives. UK: Thomson, 7-12.

Rees, C.; Mamman, A.; Braik, B. 2007. Emiratization as a strategic HRM change initiative: case study evidence from a UAE Petroleum Company, International Journal of Human Resource Management 18(1): 33-53.

Schneider, S.; Barsoux, J. 2003. Managing across cultures, 2nd edition. London: Prentice Hall

Tayeb, M. 1997. Islamic revival in Asia and Human Resource Management, Employee Relations 19(4): 352-364.

Tayeb, M. 2003. International management: theories and practices. UK: Prentice Hall.

Todnem, R. 2005. Organizational change management: a critical review, Journal of Change Management 5(4): 369-380. 